\title{
ASPEK HUKUM PELAYAN PUBLIK SECARA ONLINE PADA DIREKTORAT ADMINISTRASI HUKUM UMUM KEMENTERIAN HUKUM DAN HAK ASASI MANUSIA
}

\author{
Budi Santoso
}

Fakultas Hukum Universitas Diponegoro

\begin{abstract}
Abstrak
Perubahan pelayanan publik dari pelayanan secara manual kepada pelayanan secara online yang diselenggarakan oleh Direktorat Jenderal Administrasi Hukum Umum Kementerian Hukum dan HAM berdampak besar terhadap kemudahan dan efisiensi pendaftaran fidusia, badan hukum PT dan yayasan. Meski demikian, dari aspek hukum ada beberapa hal terkait pelayanan publik di Direktorat AHU yang harus mendapatkan kejelasan sehingga pelayanan publik yang diselenggarakan menjadi legal; misalnya soal memungkinkan ataukah tidak pelayanan diselenggarakan secara online pada peraturan terkait dengan obyek pendaftaran di Direktorat AHU. Demikian juga dengan soal sertifikat atau surat keputusan yang diberikan secara elektronik, apakah masih mengharuskan diterbitkan sertifikat atau surat keputusan yang asli.
\end{abstract}

Kata kunci: pelayanan publik, sistem online, Direktorat Administrasi Hukum Umum

\begin{abstract}
Asbtract
Changes in public service from the service manually to an online service hosted by the Direktorat Administrasi Hukum Umum of the Ministry of Justice and Human Rights have a major impact on the ease and efficiency of fiduciary registration, legal entities PT and foundations. However, the legal aspects there are several issues related to public services in the Directorate AHU that it should be clear so that the public services are organized into legal; for example about allowing or not the service be held online on the regulations relating to the registration of objects in the Directorate AHU. Likewise, the matter of a certificate or decree given electronically, whether they require a certificate or letter issued the original decision.
\end{abstract}

Keyword: public service, online system, Direktorat Administrasi Hukum Umum

\section{Pendahuluan}

Tuntutan pelayanan publik yang cepat, mudah, efisien, bebas pungutan tidak resmi, akurat, merupakan satu kebutuhan yang mendesak untuk dilakukan. Pelayanan manual yang selama ini berjalan di berbagai sektor pelayanan publik telah banyak dikeluhkan karena membutuhkan waktu yang lama, tidak efisien, biaya yang tidak murah, pungutan 
tidak resmi untuk melakukan percepatan, risiko hilangnya dokumen, dan masih banyak lagi kelemahan-kelemahan pelayanan dengan sistem manual. Hal yang sama terjadi pula pada pelayanan publik pada Direktorat Administrasi Hukum Umum (AHU) Kementerian Hukum dan HAM.

Beberapa waktu yang lalu, pelayanan publik Ditjen AHU sebagian besar masih dilakukan secara manual, atau semi online, artinya walaupun menggunakan alat bantu berupa jaringan komputer tetapi masih bersifat parsial, yaitu masih diikuti dengan tindakan yang mendasarkan pada aktifitas manusia, misalnya penandatanganan sertifikat, penyerahan sertifikat, penyerahan berkas, dan sebagainya. Keadaan menjadi berubah secara drastis semenjak dikeluarkannya Kepmenkeu No.130/KMK/2012, yang mewajibkan pendaftaran fidusia ke Kantor Pendaftaran fidusia Kementerian Hukum dan HAM, dengan ancaman pencabutan ijin usaha apabila tidak dilakukan pendaftaran fidusia.

Sejak Kepmenkeu 130/KMK/ 2012 tersebut bergulir, terjadilah arus besar pendaftaran fidusia dari lembaga pembiayaan ke kantor pendaftaran fidusia (Kementerian Hukum dan HAM). Ribuan berkas harus diselesaikan setiap bulannya. Bagi Kementerian Hukum dan HAM, serbuan pendaftaran fidusia merupakan berkah sekaligus musibah. Berkah karena banyak dana yang masuk ke Kementerian yang pada akhirnya mempunyai dana yang berlebih untuk anggaran rutinnya, tetapi merupakan musibah karena sistem yang efisien belum mendukung ke arah hal itu. Akibatnya banyak tunggakan berkas yang belum terselesaikan di sana-sini, belum lagi berkas yang tertukar ataupun hilang. Problem tersebut baru dapat teratasi sejak dilakukannya online system untuk pendaftaran fidusia dan badan hukum, sedang tahap persiapan untuk yayasan dan yang lain. Dengan iklan di media cetak dan elektronik tentang revolusi pelayanan publik Direktorat Administrasi Hukum Umum (AHU), yang dapat dilihat jutaan pasang mata masyarakat Indonesia, hal ini berarti telah disiapkan sebuah model baru pelayanan publik, khususnya untuk adminsitarsi hukum umum berupa pendaftaran fidusia, badan hukum PT, yayasan, yang tidak lain adalah pelayanan secara online system.

Langkah maju pelayanan online system oleh Ditjen AHU Kementerian Hukum dan HAM mengingatkan kita pada era perdagangan efek di Pasar Modal di masa lalu yang beranjak berubah dari sistem manual trading ke online trading, atau perdagangan 
tanpa warkat (scripless trading). Problematiknya hampir sama tetapi berbeda dalam tujuan transaksinya. Online trading adalah murni aktifitas perdagangan dalam bentuk jual beli efek, bertemunya penjual dan pembeli efek di pasar modal, sedangkan online system pada Ditjen AHU lebih bersifat pelayanan publik (public service).

Namun demikian, menurut Arrianto Mukti sistem elektronik tersebut harus dapat menjamin beberapa hal:

1. Kerahasiaan (confidentiality), artinya data transaksi harus dapat disampaikan secara rahasia sehingga tidak dapat dibaca oleh pihak-pihak yang tidak diinginkan;

2. Keutuhan (integrity), data setiap transaksi tidak boleh berubah saat disampaikan melalui salurean komunikasi;

3. Keabsahan atau keontetikan (authenticity), meliputi;

a. Keabsahan pihgak-pihak yang melakukan transaksi;

b. Keabsahan data transaksi;

c. Dapat dijadikan bukti/ tak dapat disangkal ( non-repudiation). ${ }^{1}$

Cerita mengenai keunggulan pelayanan/pendaftaran secara online dibanding secara manual kurang menarik didiskusikan, mengingat sudah banyak yang memahaminya, tetapi mendiskusikan problematik hukum pelayanan secara online menarik untuk dikaji, mengingat dapat berdampak pada sah atau tidaknya perbuatan tersebut, serta sah atau tidaknya dokumen tertentu. Problematik hukum yang dapat muncul ke permukaan dengan dilakukannya pendaftaran secara online pada Direktorat AHU Kementerian Hukum dan HAM antara lain:

1. Apakah ketentuan peraturan terkait dengan obyek pendaftaran di Direktorat AHU membolehkan dilakukannya pendaftaran secara online system?

2. Apakah pelayanan publik sebagaimana dilakukan Direktorat AHU dalam hal pendaftaran fidusia, badan hukum PT, yayasan, merupakan transaksi elektronik sebagaimana diatur dalam UU Informasi dan Transaksi Elektronik? Apakah Ditjen AHU mempunyai kapasitas untuk bertindak dalam transaksi online system tersebut?

\footnotetext{
${ }^{1}$ Arrianto Mukti., 1997, Studi Perbandingan Sistem-sistem Perdagangan di Internet dan Desain Protokol cek Bilyet Giro Digital.,
} 
3. Apakah pencetakan sertifikat fidusia dan pengesahan badan hukum oleh Menteri Hukum dan HAM secara mandiri oleh pendaftar dapat dibenarkan secara hukum?

\section{Pembahasan}

\section{Beberapa Peraturan terkait Pendaftaran Online System}

\section{Pendaftaran Perseroan Terbatas ( PT)}

Pasal 9 UU No.40 tahun 2007 tentang Perseroan terbatas menyebutkan bahwa: "Untuk memperoleh Keputusan Menteri mengenai pengesahan badan hukum Perseroan sebagaimana dimaksud dalam Pasal 7 ayat (4), pendiri bersama-sama mengajukan permohonan melalui jasa teknologi informasi sistem administrasi badan hukum secara elektronik Kepada Menteri dengan mengisi format isian yang memuat sekurang-kurangnya ..."

Lebih lanjut dalam Peraturan Menteri Hukum dan Hak Asasi Manusia Republik Indonesia Nomor: M-01-HT.01-10 tahun 2001 tentang Tata Cara Pengajuan Permohonan Pengesahan Badan Hukum dan Persetujuan Perubahan Anggaran Dasar, Penyampaian Pemberitahuan Perubahan Anggaran Dasar dan Perubahan Data Perseroan. Dalam pasal 2 (1) disebutkan bahwa pengajuan permohonan pengesahan badan hukum Perseroan dilakukan oleh Notaris sebagai kuasa dari para pendiri. Pasal 2 (2) Notaris sebagaimana dimaksud dalam ayat (1) mengajukan permohonan kepada Menteri atau pejabat yang ditunjuk. Pasal 3 (1) Permohonan sebagaimana dimaksud dalam pasal 2 ( 2) diajukan oleh Notaris melalui Sisminbakum dengan cara mnengisi FIAN $^{2}$ Model I setelah pemakaian nama disetujui Menteri atau pejabat yang ditunjuk dan dilengkapi keterangan mengenai dokumen pendukung. Sedangkan yang dimaksud dengan Sisminbakum dalam peraturan Menteri tersebut, adalah Sistem Administrasi Badan Hukum, yaitu jenis pelayanan yang diberikan pada masyarakat dalam proses pengesahan Badan Hukum Perseroan terbatas dan proses pemberian persetujuan perubahan anggaran dasar, penerimaan pemberiathuan perubahan anggaran dasar dan

\footnotetext{
2 FIAN adalah singkatan Format isian Akta Notaris. FIAN Model I adalah format isian unutk permohonan pengesahan status badan hukum perseroan. FIAN Model II adalah FIAN unutk permohonan persetujuan Perubahan Anggaran dasar perseroan. FIAN Model III adalah FIAN unutk penyampaian pemberitahuan perubahan Anggaran dasar dan Perubahan data Perseroan yang diwajibkan oleh UU No.40 tahun 2007 tentang perseroan terbatas.
} 
perubahan data perseroan serta pemberian informasi lainnya secara elektronik, yang diselenggarakan oleh Direktorat Jenderal Administrasi Hukum Umum.

Berdasarkan ketentuan di atas dapat disimpulkan bahwa UU PT telah mengakomodasi pendaftaran Perseroan yang didahului dengan pengajuan nama perseroan secara elektronik. Dengan demikian tidak terjadi perbedaan prinsip antara ketentuan peraturan yang mendasari, dalam hal ini UU PT, dengan implementasi pendaftaran perseroan secara elektronik yang dilakukan oleh Ditjen AHU Kementrian Hukum dan HAM. Namun demikian problematika hukum akan muncul manakala pemohon diberikan kewenangan untuk mencetak sendiri dengan cara melakukan perintah print out Surat keputusan Menteri mengenai pengesahan badan hukum. Apakah hasil printout SK Pengesahan Menteri mengenai pengesahan badan hukum perseroan terbatas mempunyai kedudukan yang sama dengan SK aslinya? Apakah SK Asli pengesahan badan hukum oleh Menteri masih perlu dibuat? Dalam hal ini perlu dilakukan penelaahan secara mendalam.

\section{Perdaftaran Jaminan Fidusia}

Pasal 11 UU No. 42 tahun 1999 tentang Fidusia menyebutkan bahwa: "Benda yang dibebani dengan jaminan Fidusia wajib didaftarkan”. Pada Pasal 12 disebutkan, 1) Pendaftaran dilkakukan pada kantor Pendaftaran Fidusia, 2) Kantor Pendaftaran Fidusia berada dalam lingkup tugas Departemen Kehakiman.

Pasal 14 menyebutkan bahwa Kantor Pendafraran Fidusia menerbitkan dan menyerahkan kepada penerima Fidusia Sertifikat Jaminan Fidusia pada tanggal yang sama dengan tanggal penerimaan permohonan pendaftaran.

Berdasarkan ketentuan di atas, UUJF tidak mengatur secara jelas mengenai teknis bagaimana pendaftaran fidusia tersebut dilakukan. Dengan demikian tidak dipermasalahkan apakah dilakukan secara manual ataukah dilakukan secara online system. Berbeda dengan ketentuan untuk pendaftaran Perseroan Terbatas yang secara jelas menyebutkan dilakukan secara elektronik. Hal ini berarti hal-hal yang berkaitan dengan teknis pendaftaran fidusia diserahkan sepenuhnya pada kantor Pendaftaran Fidusia, dalam hal ini Kementrian Hukum dan HAM.

Problematik hukum akan muncul berkaitan dengan ketentuan pasal 14 yang menyebutkan bahwa kantor Pendaftaran fidusia berkewajiban menerbitkan dan 
menyerahkan kepada penerima fidusia Sertifikat Jaminan Fidusia. Berdasarkan ketentuan ini maka Kantor Pendaftaran fidusia berkewajiban menerbitkan dan menyerahkan sertifikat jaminan fidusia. Dengan teknologi yang ada sekarang memungkinkan pencetakan sertifikat jaminan fidusia oleh pendaftar fidusia sendiri, setelah aplikasi fidusia dilakukan. Apakah pencetakan sertifikat jaminan Fidusia oleh pendaftar fidusia tidak bertentangan dengan ketentuan pasal 14 UUJF? Dalam hal ini harus dipisahkan antara penerbitan dan pencetakan sertifikat jaminan fidusia. Secara elektronik, kantor Pendaftaran Fidusia telah menyiapkan dokumen sertifikat fidusia tersebut dalam sistem elektronik, sedangkan yang dilakukan oleh pendaftar fidusia adalah hanya melakukan perintah cetak sertifikat setelah semua proses pendaftaran dilakukan secara benar. Dengan demikian pencetakan sertifikat fidusia oleh pendaftar tidak menggantikan kedudukan Kantor pendaftaran fidusia dalam menerbitkan Sertifikat Jaminan Fidusia. Bagaimana dengan kewajiban Kantor Pendaftaran Fidusia untuk menyerahkan Sertifikat Jaminan Fidusia? Apakah dengan pencetakan sendiri melalui perintah print out pada komputer menjadikan kewajiban menyerahkan sertifikat Jaminan Fidusia oleh Kantor Pendaftaran Fidusia menjadi tidak dilakukan? Kalimat "menyerahkan" tidak diartikan secara apa adanya, yang menuntut bertemunya kedua belah pihak yang akan menyerahkan dengan pihak yang akan menerima penyerahan, akan tetapi terminologi menyerahkan dapat saja terjadi barang yang akan diserahkan telah tersedia di suatu tempat sedangkan pihak yang akan menerima tinggal mengambilnya dengan melakukan langkah-langkah tertentu. Dengan demikian dalam sistem elektronik, dokumen yang akan diserahkan tersebut telah ada dalam sistem elektronik, tinggal calon penerima dokumen tersebut melakukan langkah-langkah tertentu untuk kemudian melakukan print out dokumen yang dibutuhkan, dalam hal ini sertifikat jaminan fidusia. Dengan demikian aktifitas pendaftaran secara online sebagaimana dilakukan oleh Ditjen AHU, untuk pendaftaran jaminan fidusia, yang menggunakan jaringan elektronik, maka sebenarnya perbuatan hukum sebagaimana diamanatkan pasal 14 UUJF, yaitu menerbitkan dan menyerahkan sertifikat jaminan fidusia terjadi pada saat bersamaan, yaitu pada saat pendaftar melakukan pencetakan sertifikat jaminan fidusia dari sistem, pada saat bersamaan telah terjadi penyerahan sertifikat dari Kantor Pendaftaran fidusia pada pendaftar. 


\section{Pendaftaran Yayasan}

Dalam pasal 11 UU No. 28 tahun 2004 tentang Perubahan UU No. 16 tahun 2001 tentang Yayasan disebutkan bahwa:

1) Yayasan memperoleh status badan hukum setelah akta pendirian yayasan memperoleh pengesahan dari Menteri;

2) Untuk memperoleh pengesahan, pendiri atau kuasanya mengajukan permohonan kepada Menteri melalui Notaris yang membuat akta pendirian yayasan;

3) Notaris wajib menyempaikan permohonan pengesahan pada Menteri dalam jangka waktu paling lambat 10 hari terhitung sejak tanggal akta pendirian yayasan ditanda tangani.

Berdasarkan ketentuan di atas dapat disimpulkan bahwa UU Yayasan tidak mengatur secara detail mengenai bagaimana mekanisme pendaftaran yayasan tersebut pada Kementrian Hukum dan HAM. UU Yasasan tidak mempersoalkan apakah dilakukan secara manual ataukah secara elektronik. Hal ini berarti bahwa pelaksanaan pendaftaran Yayasan secara online system tidak bertentangan dengan ketentuan UU Yayasan.

\section{Keterkaitan Pendaftaran Online System dengan UU Informasi dan Transaksi Elektronik dan Posisi Ditjen AHU}

Secara visual system yang dibangun untuk aplikasi atau pendaftaran fidusia, badan hukum perseroan, yayasan, melibatkan dua pihak, yaitu pendaftar (dalam hal ini perorangan, biasanya Notaris selaku pemegang kuasa) dengan pihak pemerintah (dalam hal ini adalah Kementerian Hukum dan HAM, khususnya Ditjen AHU). Aplikasi tersebut awalnya dilakukan secara manual, artinya terdapat hubungan langsung antara pendaftar dan Kementerian Hukum dan HAM, terdapat penyerahan dokumen tertentu dari pendaftar kepada pihak Kementerian Hukum dan HAM. Namun demikian, dalam perkembangan berikutnya mata rantai keterhubungan langsung antara pendaftar dan Kementerian Hukum dan HAM dipisahkan oleh suatu sistem, yaitu perangkat elektronik komputer. Tidak terdapat kontak langsung antara pendaftar dengan Kementerian Hukum dan HAM. Pendaftar cukup terhubung dengan aplikasi komputer yang terkoneksi dengan Kementerian Hukum dan HAM, dalam hal ini Ditjen AHU. Dengan demikian pola yang semula bersifat manual telah diubah dengan sistem elektronik. Hal 
ini berarti bahwa ketentuan-ketentuan yang diatur dalam UU No. 12 tahun 2008 tentang Informasi dan Transaksi Elektronik berlaku dalam kaitannya dengan pendaftaran online system untuk fidusia, badan hukum perseroan, yayasan, dan sebagainya.

Masalahnya adalah, apakah aktifitas pendaftaran online tersebut dapat digolongkan ke dalam transaksi elektronik, sebagaimana diatur dalam UUITE?

Dalam Penjelasan Umum angka 2 UUITE disebutkan bahwa transaksi elektronik adalah perbuatan hukum yang dilakukan dengan menggunakan komputer, jaringan komputer, dan atau media elektronik lainnya. Melihat rumusan tersebut maka pendaftaran online system tersebut memenuhi unsur tersebut, yang mana terdapat perbuatan hukum tertentu, yaitu pendaftaran fidusia, perseroan, dan yayasan. Masalahnya adalah apakah pendaftaran online tersebut perbuatan hukum? Terminologi "pendaftaran" saja barangkali tidak secara otomatis merupakan perbuatan hukum. Namun demikian apabila perbuatan pendaftaran tersebut dilakukan dalam kaitannya untuk melaksanakan ketentuan peraturan, apalagi tanpa perbuatan pendaftaran membawa akibat hukum tertentu, maka perbuatan pendaftaran tersebut memenuhi kualifikasi sebagai perbuatan hukum. Dalam pendaftaran online saat ini juga mendasarkan pada perangkat komputer yang terkoneksi dengan jaringan di Ditjen AHU, sehingga perbuatan pendaftaran secara online system pada Ditjen AHU memenuhi kriteria sebagai transaksi elektronik, sebagaimana diatur dalamn UUITE.

Masalah berikutnya adalah, apakah transaksi elektronik tersebut dapat bersifat non-komersial? Apakah pelayanan pemerintah secara elektronik, seperti halnya pendaftaran secara online, dapat dikategorikan sebagai transaksi elektronik?.

Problematika tersebut di atas terjawab dengan melihat ketentuan pasal 17 UUITE yang menyebutkan bahwa penyelenggaraan transaksi elektronik dapat dilakukan dalam lingkup publik ataupun privat. Dalam penjelasannya disebutkan bahwa undangundang ini memberikan peluang terhadap pemanfaatan teknologi informasi oleh penyelenggara negara, orang, badan usaha, dan atau masyarakat. Dengan demikian Kementerian Hukum dan HAM, dalam kaitannya dengan penyelenggaraan pendaftaran online, berposisi sebagai penyelenggara negara yang melakukan transaksi elektronik dalam lingkup publik. 
Bagaimana gambaran posisi masing-masing pihak dalam hal pendaftaran secara online, baik fidusia, perseroan, atau yayasan, pada Ditjen AHU, bila ditinjau dari UUITE?

Pendaftaran fidusia, perseroan, yayasan pada Ditjen AHU secara visual dapat digambarkan sebagai berikut. Notaris, sebagai pemegang kuasa pendaftaran, melakukan aplikasi melalui jaringan komputer setelah sebelumnya melakukan pembayaran PNBP pada suatu bank yang ditunjuk untuk itu. Jaringan komputer yang digunakan notaris terhubung dengan server pada Direktorat jenderal Administrasi Hukum Umum pada kementrian Hukum dan HAM Jakarta. Apabila aplikasi yang dilakukan notaris tersebut benar maka notaris dalam melakukan print out tanda bukti pendaftaran termasuk di dalamnya sertifikat fidusia (apabila pendaftaran fidusia), SK Pengesahan Badan Hukum (bila pendaftaran pengesahan badan hukum perseroan). Dengan demikian dalam kaitannya dengan pendaftaran secara online, terdapat dua subyek hukum, yaitu pendaftar (dalam hal ini notaris) dan Pemerintah (dalam hal ini Kementerian Hukum dan HAM, Ditjen AHU), sedangkan yang menjadi obyek adalah dokumen.

Apabila persoalan pendaftaran secara online tersebut ditinjau dari UUITE, maka pendaftar (dalam hal ini Notaris) berposisi sebagai pengguna, yang dapat berwujud orang atau badan usaha. Sedangkan aktifitas melakukan pendaftaran secara online tersebut disebut dengan transaksi elektronik. Data yang dimasukkan ke dalam sistem elektronik oleh notaris pada saat melakukan aplikasi disebut dengan informasi elektronik, yaitu satu atau sekumpulan data elektronik, termasuk tetapi tidak terbatas pada tulisan, suara, gambar, peta, rancangan, foto, elektronik data interchange (EDI), surat elektronik, telegram, teleks, telekopi atau sejenisnya, huruf, tanda, angka, kode akses, simbol atau perforasi yang telah diolah yang memiliki arti atau dapat dipahami oleh orang yang mampu memahaminya. Keterhubungan antara komputer yang digunakan oleh notaris untuk melakukan aplikasi secara online dengan komputer yang berada di Ditjen AHU Kementerian Hukum dan HAM, disebut dengan jaringan sistem elektronik, yaitu terhubungnya dua sistem elektronik atau lebih, yang bersifat tertutup atau terbuka. Adapun posisi Kementerian Hukum dan HAM, dalam hal ini Ditjen AHU, berposisi sebagai penyelenggara sistem elektronik, yaitu pemanfaatan sistem elektronik oleh penyelenggara negara, orang, badan usaha, dan atau masyarakat. 


\section{Masalah Fungibility}

Persoalan hukum akan muncul ketika seorang notaris yang telah melakukan aplikasi secara online untuk fidusia ataupun pendaftaran perseroan untuk memperoleh pengesahan badan hukum dari Kementerian Hukum dan HAM, yaitu pada saat notaris melakukan perintah print atau cetak sertifikat fidusia ataupun SK pengesahan Badan Hukum dari Menteri Hukum dan HAM. Apakah sertifikat fidusia dan SK pengesahan Badan Hukum tersebut mempunyai kekuatan pembuktian yang sama dengan aslinya?

Apakah hukum dapat membedakan mana sertifikat yang asli dan mana yang bukan? Apakah sertifikat fidusia aslinya masih harus dibuat? Apakah SK Pengesahan badan hukum yang asli harus juga dibuat? Apakah sertifikat atau SK Pengesahan badan hukum hasil dari print out tersebut berstatus sebagai pengganti atau turunan ataukah asli? Persoalan-persoalan hukum tersebut akan muncul sekitar aplikasi secara online pada Ditjen AHU.

Problematika tersebut di atas sebenarnya berkisar pada persoalan sekitar fungibility atau fungible, artinya terdapat dua hal atau benda yang memiliki identitas yang sama, sedemikian identiknya sehingga segala sesuatunya menyangkut unsur, bentuk dan ukuran, serta nilai ekonomis atau pemanfatannya benar-benar sama.

Namun demikian penerapan "nilai ekonomis" tidak harus diartikan secara harfiah, tetapi menekankan pada tujuannya. Sebagai contoh ketentuan pasal 1763 BW yang menyebutkan bahwa "siapa yang menerima pinjaman diwajibkan mengembalikannya dalam jumlah dan keadaan yang sama ...”. Kalimat "keadaan yang sama" tidaklah berarti pengembalian pinjaman tersebut harus sama jumlahnya dan sama keadaan uang pada saat dipinjam dengan saat dikembalikan, yaitu sama nomor seri uangnya. Dalam kondisi ini terdapat faktor particular circumstances, yang membolehkan secara kasuistik untuk mengartikan fungibility berdasarkan jumlah uang yang dipinjam berdasarkan patokan ekonomis. ${ }^{3}$

Apakah sertifikat fidusia dan SK pengesahan badan hukum yang dicetak oleh notaris melalui perintah print pada komputer berstatus sebagai pengganti, turunan, derivatif ataukah asli? Apabila sertifikat fidusia dan SK Pengesahan badan hukum perseroan dari Kementerian Hukum dan HAM, tidak diterbitkan lagi, selain yang diperoleh dengan jalan print dari sistem elektronik, maka sertifikat fidusia dan SK

\footnotetext{
${ }^{3}$ PT Kliring Deposit Efek Indonesia, Aspek Hukum Pasar Modal, Transaksi dan Penyelesaian Transaksi Efek tanpa Sertifikat, Rangkuman Diskusi panel , Niaga Tower, 3 Mei 1994, hal 26-27
} 
pengesahan badan hukum tersebut berstatus sebagai pengganti atau substitusi. Tetapi apabila sertifikat fidusia dan SK Pengesahan badan hukum yang asli masih diterbitkan, maka berstatus sebagai turunan atau derivatif. Sebagai akibatnya fungsi sebagai pembuktian akan berbeda antara dokumen yang asli dibandingkan dengan dokumen yang bersifat turunan atau derivatif.

Masalah fungibilitas berkait erat dengan fungsi dokumen sebagai pengganti atau substitusi dan bukan sebagai turunan atau derivatif. Hal itu disebabkan karena karakter, fungsi atau manfaat yang melekat dari dokumen asli akan tergantikan oleh dokumen penggantinya. Dengan demikian sebaiknya dalam kaitannya dengan pendaftaran secara online pada Kementerian Hukum dan HAM, dalam hal ini Ditjen AHU, tidak diterbitkan lagi sertifikat fidusia yang asli ataupun SK Pengesahan badan hukum yang asli, setelah semuanya dilakukan melalui sistem elektronik. Hal ini untuk mendukung agar fungsi, karakter, nilai manfaat, dari sertifikat Fidusia dan SK pengesahan badan hukum yang dicetak dari sistem elektronik fungible dengan aslinya.

Pemaknaan fungible pada fungsi dokumen sebenarnya merupakan pengembangan makna fungible yang dikhususkan dalam ranah hukum atau legal term. Pada awalnya fungible diperuntukkan untuk penggantian benda fisik yang menggantikan benda fisik yang lain, sebagaimana disebutkan dalam pengertian Fungible menurut kamus Law Dictionary diberikan arti sebagai "a term apllied to goods that are interchangeable or capable of substitution by nature or agreement. Dalam UCC, oil, grain and coal are examples of naturally fungible goods. When storing fungible goods, warehousemen are exempt from the legal requirement of keeping stored goods from one depositor separate from the goods of another. Securities of the same issue are considered fungible; hence a person obligated to deliver securities may deliver any security of the specified issue. ${ }^{4}$

\section{Kesimpulan}

Berdasarkan uraian di atas, maka dapat disimpulkan bahwa, pertama, dari keseluruhan pelayanan publik yang terdapat pada Direktorat Adminitrasi Hukum Umum, hanya pendaftaran PT yang disebutkan secara jelas pendaftarannya bisa dilakukan secara elektronik, termasuk online. Sedangkan pada pendaftaran jaminan

\footnotetext{
${ }^{4}$ Steven H. Gifis., 1984, Law Dictionary, Second Edition, Barrons Educational Series,INC. p.200
} 
fidusia dan pendaftaran yayasan, peraturan terkait tidak menyebutkan secara jelas bagaimana pendaftaran tersebut dilakukan; dan karenanya pendaftaran secara online tidak berarti bertentangan dengan perundang-undangan. Kedua, pelayanan publik secara online sejauh ini masih menimbulkan soal terkait sertifikat yang diterbitkan, apakah dengan diberikannya sertifikat secara elektronik atau online masih memerlukan penerbitan secara cetak, yang dalam artikel ini disarankan untuk tidak diterbitkan versi cetaknya agar menjadi jelas kedudukan dan kekuatan sertifikat yang diterbitkan atau diberikan secara elektronik.

\section{Daftar Referensi}

Arrianto Mukti, Studi Perbandingan Sistem-sistem Perdagangan di Internet dan Desain Protokol cek Bilyet Giro Digital, 1997.

PT Kliring Deposit Efek Indonesia, "Aspek Hukum Pasar Modal, Transaksi dan Penyelesaian Transaksi Efek tanpa Sertifikat”, Rangkuman Diskusi Panel, Niaga Tower, 3 Mei 1994.

Steven H. Gifis, Law Dictionary, Barrons Educational Series, INC., edisi kedua. 